\title{
Kajian Perspektif Hukum Terhadap Hak Atas Wilayah Serta Lingkungan Yang Sehat dan Bersih Bagi Masyarakat Pesisir
}

\author{
Iwan Permadi \\ Fakultas Hukum Universitas Brawijaya \\ Permadi_iwan@yahoo.com
}

\begin{abstract}
Environmental degradation of coastal resources in Indonesia from year to year more and more alarming. Damage to ecosystems, especially in the mangrove, coral reefs and estuarine (river mouth) caused by the many destructive activities in coastal areas. The coastal area is also part of the source of life and livelihood, if not protected would threaten the loss of environmental rights for the communities themselves. In the management of natural resources and the environment, the people must be placed as of primary importance. Fully state acts as caretaker and organizer of policy instruments aimed at protecting and promoting the human right to the environment you want to damage the coastal environment is the result of interaction between humans and coastal resources are excessive and do not pay attention kaedah-kaedah sustainability and carrying capacity of the environment. Violation of environmental rights can be interpreted as a threat to civilization coastal communities that will lead to the violation of Human Rights.
\end{abstract}

Keywords: Right. Environment, Society, Coastal.

\begin{abstract}
Abstrak
Degradasi lingkungan sumber daya pesisir di Indonesia dari tahun ke tahun semakin mengkhawatirkan. Kerusakan ekosistem terutama pada mangrove, terumbu karang dan estuaria (muara sungai) banyak ditimbulkan oleh kegiatan destruktif di wilayah pesisir. Wilayah pesisir juga menjadi bagian dari sumber kehidupan dan penghidupan masyarakat, apabila tidak dilindungi akan mengancam hilangnya hak atas lingkungan bagi masyarakat pesisir sendiri. Dalam pengelolaan sumber daya alam dan lingkungan hidup, rakyat harus ditempatkan sebagai kepentingan yang utama. Negara sepenuhnya berperan sebagai instrumen pengurus dan penyelenggara kebijakan yang ditujukan untuk melindungi dan memajukan hak asasi manusia atas lingkungan hidup Semua kerusakan lingkungan pesisir tersebut adalah hasil interaksi antara manusia dengan sumber daya pesisir yang berlebihan dan tidak memperhatikan kaedah-kaedah kelestarian dan daya dukung lingkungannya. Pelanggaran hak atas lingkungan tersebut dapat dimaknai sebagai ancaman terhadap peradaban masyarakat pesisir yang akan mengarah pada pelanggaran Hak Asasi Manusia.
\end{abstract}

Kata Kunci : Hak. Lingkungan, Masyarakat, Pesisir.

\section{Pendahuluan}

Indonesia sebagai suatu negara

kepulauan terdiri dari 17.508 buah pulau

besar dan kecil yang secara keseluruhan memiliki panjang garis pantai sekitar $81.000 \mathrm{~km}$. Sebagian daerah tersebut ditumbuhi hutan mangrove dengan lebar beberapa meter sampai puluhan 
kilometer. Masing-masing kawasan pantai dan hutan mangrove pada pulaupulau diatas memiliki historis perkembangan yang berbeda-beda. Perubahan keadaan kawasan pantai dan hutan mangrove sangat dipengaruhi oleh faktor alam dan faktor campur tangan manusia. Diperkirakan $60 \%$ penduduk Indonesia hidup dan bermukim di daerah pantai. Dari 64.439 desa di Indonesia, terdapat 4.735 desa yang dapat dikategorikan sebagai desa pantai. Bahkan, masyarakat yang bermukim di wilayah kota pantai sudah mencapai sekitar $100 \quad$ juta orang (http://www.dephut.go.id/uploads/INFORMAS I/RRL/STS_MAngrove.HTM, "Perubahan Kondisi Kawasan Pantai”, di unduh pada 7 Juli 2016).

Desa-desa pesisir umumnya merupakan kantong-kantong kemiskinan struktural yang acapkali lebih kronis. Sebagaian besar masyarakat nelayan yang bertempat tinggal di desa-desa pantai umumnya taraf kesejahteraan hidupnya rendah dan tak menentu. Kesulitan mengatasi kebutuhan hidup sehari-hari dan kemiskinan di desa-desa pantai telah menjadikan penduduk di kawasan ini harus menanggung beban kehidupan yang berat, berkutat dengan perangkap utang yang sepertinya tak pernah ada habishabisnya, dan tidak dapat dipastikan pulakapan masa berakhirnya (Bagong Susanto, 2016).

Kegiatan di wilayah pesisir saat ini sudah pada tahapan yang cukup memprihatinkan. eksploitasi sumber daya pesisir pesisir secara besar-besaran oleh pihak tertentu telah mengakibatkan degradasi lingkungan secara cepat dan juga menimbulkan kemiskinan bagi masyarakatnya. Kenyataan menunjukkan lingkungan pesisir semakin rusak oleh pihak-pihak tertentu., adanya penambangan pasir dan reklamasi merupakan contoh konkrit saat ini. Lingkungan pesisir diposisikan sebagai obyek eksploitasi, menambang pasir tanpa kontrol, menebangi hutan mangrove, mencemari air tanpa kendali, dan tindakan sewenang-wenang lainnya. Pelanggaran terhadap norma lingkungan di wilayah pesisir ini mengakibatkan bencana dan tingginya angka kemiskinan masyarakat di wilayah pesisir khususnya nelayan tradisional. Perusakan lingkungan pesisir oleh pihak tertentu atau korporasi telah menyebabkan penderitaan dan pelanggaran hak asasi 
manusia (HAM) terhadap bagian terbesar manusia lainnya yaitu masyarakat pesisir.

Perlindungan bagi hak masyarakat pesisir atas wilayah pesisir yang menjadi sumber penghidupan dan kehidupan serta lingkungan yang sehat dan bersih menjadi penting ditegaskan dan ditegakkan, oleh karenanya tulisan ini akan mengkaji dalam perspektif hukum kedudukan hakhak tersebut secara konstitusional.

\section{Pembahasan}

\section{Hak Masyarakat atas Pengelolaan Wilayah Pesisir}

Wilayah pesisir dan lautan mempunyai batasan yang tidak terlepas dari tujuan penggunaan atau pengelolaannya. Membatasi wilayah dalam satuan pengelolaan berguna untuk mengidentifikasi segenap interaksi fungsional (seperti aliran materi dan energi) antar komponen di dalam satuan (sistem) wilayah pengelolaan dan interaksinya dengan wilayah pengelolaan lainnya. Pengetahuan tentang batasan "ekologis" tersebut menjadi dasar bagi perencanaan dan pengelolaan pembangunan sumberdaya wilayah pesisir dan lautan secara berkelanjutan ( Rokhmin Dahuri dan Iwan Nugroho, 2012 : 276).
Batasan wilayah atas dasar kriteria ekologis sekalipun dianggap mengikuti kaidah-kaidah konservasi namun tidak dapat diberlakukan. Akibatnya, para perencana dan pengelola cenderung memilih batasan wilayah pesisir menurut kriteria garis lurus secara arbiter dan administratif. Oleh karena itu, untuk kepentingan pengelolaan sebaiknya tidak menetapkan batas wilayah pesisir secara kaku. Akan lebih bermakna jika penetapan batas wilayah adalah atas dasar tujuan pengelolaan itu sendiri. Misalnya, batasan wilayah pesisir untuk tujuan pengelolaan bahaya banjir akan berbeda dengan batasan untuk tujuan pengelolaan pengendalian pencemaran, penambangan terumbu karang, pemanfaatan sumberdaya ikan secara lestari, dan sebagainya. Akan lebih baik lagi, jika batas ke arah darat dari suatu wilayah pesisir dapat ditetapkan sebanyak dua macam, yaitu batas untuk wilayah perencanaan (planning zone) dan batas untuk wilayah pengaturan (regulation zone) atau pengelolaan keseharian (dayto-day management). Wilayah perencanaan sebaiknya meliputi seluruh daerah daratan (hulu) apabila terdapat kegiatan manusia (pembangunan) yang 
dapat menimbulkan dampak secara nyata (significant) terhadap lingkungan dan sumberdaya di pesisir. Oleh karena itu, batas wilayah pesisir ke arah darat untuk kepentingan perencanaan (planning zone) dapat sangat jauh ke arah hulu, misalnya Kota Bandung untuk wilayah pesisir dari DAS Citarum ( Rokhmin Dahuri dan Iwan Nugroho, 2012: 277).

Undang-undang Republik Indonesia Nomor 26 tahun 2007 tentang Penataan Ruang, Lembaran Negara Republik Indonesia Tahun 2007 Nomor 68, Tambahan Lembaran Negara Republik Indonesia Nomor 4725, selanjutnya disingkat UU 26/2007, memberikan definisi wilayah sebagai beikut : "Wilayah adalah ruang yang merupakan kesatuan geografis beserta segenap unsure terkait yang batas dan sistemnya ditentukan berdasarkan aspek administratif dan/atau aspek fungsional".

Berdasarkan pendekatan secara ekologis, wilayah pesisir merupakan kawasan daratan yang masih dipengaruhi oleh proses-proses kelautan seperti pasang surut dan intrusi air laut dan kawasan laut yang masih di pengaruhi oleh proses-proses daratan, seperti sedimentasi dan pencemaran ( Rokhmin Dahuri dan Iwan Nugroho, 2012: 63).

Pasal 33 ayat (3) UUD 1945 mengatur bahwa " Bumi, air dan kekayaan alam yang terkandung di dalamnya dikuasi oleh negara dan dipergunakan untuk sebesar-besar kemakmuran rakyat ". Hal tersebut dipakai dasar oleh Pasal 2 ayat (1) Undang-undang Nomor 5 Tahun 1960 tentang Peraturan Dasar Pokok-Pokok Agraria (LN 1960-104, TLN 2043) atau menurut Diktum Kelima disebut Undangundang Pokok Agraria, selanjutnya disingkat UUPA, bahwa "Atas dasar ketentuan dalam Pasal 33 ayat (3) Undang-undang PDasar dan hal-hal sebagai yang dimaksud dalam Pasal 1, bumi, air dan ruang angkasa, termasuk kekayaan alam yang terkandung di dalamnya itu pada tingkatan tertinggi dikuasai oleh Negara, sebagai organisasi kekuasaan seluruh rakyat.

Berdasarkan Pasal 2 ayat (2) UUPA, atas dasar hak menguasai dari negara tersebut, negara mempunyai wewenang untuk :

a. Mengatur dan menyelenggarakan peruntukan, penggunaan, persediaan, 
dan pemeliharaan bumi, air, dan ruang angkasa ;

b. Menentukan dan mengatur hubunganhubungan hukum antara orang-orang dengan bumi, air dan ruang angkasa ;

c. Menentukan dan mengatur hubunganhubungan hukum antara orang-orang dan perbuatan-perbuatan hukum yang mengenai bumi, air dan ruang angkasa.

Ketiga kewenangan tersebut merupakan landasan untuk mewujudkan cita-cita mencapai sebesar-besarnya kemakmuran rakyat dalam arti kebahagiaan, kesejahteraan dan kemerdekaan dalam masyarakat dan negara hukum Republik Indonesia.

Upaya mewujudkan kesejahteran dan kemakmuran rakyat melalui kewenangan negara juga dilakukan dalam mengatur pemanfaatan ruang di wilayah pesisir. Pengaturan dalam hukum nasional terkait pengelolaan wilayah pesisir wajib menjaga, melindungi dan melestarikan lingkungan. Pasal 33 ayat (3) UUD 1945 juga menjadi landasan pengaturan pengelolaan wilayah pesisir yang dituangkan dalam Undang-Undang Nomor 27 Tahun 2007 tentang
Pengelolaan Wilayah Pesisir dan PulauPulau Kecil (LN 2007-84, TLN 4739) disahkan di Jakarta tanggal 17 Juli 2007, selanjutnya disingkat UU 27/2007, dalam konsideran menimbang menyatakan :

a. bahwa wilayah pesisir merupakan bagian dari sumber daya alam yang dianugerahkan oleh Tuhan Yang Maha Esa dan merupakan kekayaan yang dikuasai oleh negara, yang perlu dijaga kelestariannya dan dimanfaatkan untuk sebesar-besar kemakmuran rakyat, baik bagi generasi sekarang maupun bagi generasi yang akan datang;

b. bahwa wilayah pesisir memiliki keragaman potensi sumber daya alam yang tinggi, dan sangat penting bagi pengembangan sosial, ekonomi, budaya, lingkungan, dan penyangga kedaulatan bangsa, oleh karena itu perlu dikelola secara berkelanjutan dan berwawasaan global, dengan memperhatikan aspirasi dan partisipasi masyarakat, dan tata nilai bangsa yang berdasarkan norma hukum nasional;

c. bahwa berdasarkan pertimbangan sebagaimana dimaksud dalam huruf a, dan huruf b, perlu membentuk 
Undang-Undang tentang Pengelolaan

Wilayah Pesisir dan Pulau-Pulau

Kecil (konsideran UU 27/2007).

Merujuk pada Pasal 33 ayat (3) UUD 1945 dan konsideran menimbang pada UU 27/2007 masyarakat pesisir berhak untuk mengelola dan memanfaatkan wilayah pesisir bagi sebesar-besarnya kemakmuran rakyat, karena mereka juga menjadi bagian dari rakyat Indonesia. Dengan demikian wilayah pesisir yang menjadi sumber kehidupan dan penghidupan masyarakat berhak dimanfaatkan oleh siapapun sebagai rakyat Indonesia tanpa membedakan apakah dia masyarakat biasa atau pengusaha/pemodal. Oleh karenanya wilayah pesisir ini bukan ditujukan hanya pada pihak-pihak tertentu yang dapat dengan mudah mengesampingkan hak masyarakat pesisir untuk memanfaatkan ruang pesisirnya.

Masyarakat di wilayah pesisir yang dimaksudkan dalam tulisan ini adalah masyarakat sebagaimana diatur dalam Pasal 32 UU 1/2014 sebagai perubahan dari UU 27/2007, mendefinisikan masyarakat di wilayah pesisir adalah masyarakat yang terdiri atas Masyarakat
Hukum Adat, Masyarakat Lokal, dan Masyarakat Tradisional yang bermukim di wilayah pesisir dan pulau-pulau kecil. Lapisan masyarakat yang dimaksud dalam Pasal 32 UU 1/2014 inilah yang juga berhak untuk mengelola dan memanfaatkan wilayah pesisirnya tanpa harus mengalami perbedaan dan perlakuan yang diskriminatif dengan tetap mengedepankan keberlangsungan dan kelestarian lingkungan pesisir.

Hak Atas Lingkungan dalam Perspektif Hak Asasi Manusia (HAM) Bagi Masyarakat Pesisir

Memahami hakekat HAM, harus difahami pengertian dasar tentang hak, The Universal Declaration of Human Right (Deklarasi Universal Hak Asasi Manusia-DUHAM) yang dirumuskan dan dideklarasikan oleh PBB tahun 1948, Pasal 1 Deklarasi HAM ini menyebutkan bahwa seluruh umat manusia dilahirkan merdeka dan setara dalam martabat dan hak, mereka dikaruniai akal serta nurani dan harus saling bergaul dalam semangat persaudaraan. Deklarasi PBB memberikan penjelasan seperangkat hakhak dasar manusia yang tidak boleh dipisahkan dari keberadaannya sebagai manusia (Mulya Lubis, 1987:5). 
Hak Asasi Manusia (HAM) merupakan hak universal yang dimiliki oleh manusia semata-mata karena posisinya sebagai manusia. Pandangan ini menunjukkan secara tidak langsung bahwa karakteristik seperti ras, jenis kelamin, agama, kedudukan sosial dan kewarganegaraan tidak relevan untuk mempersoalkan apakah seseorang memiliki atau tidak memiliki HAM. Hal ini menyiratkan bahwa hak-hak tersebut dapat diterapkan di seluruh dunia. Salah satu ciri khusus dari HAM yang berlaku sekarang yaitu bahwa hal itu merupakan hak internasional. Kepatuhan terhadap hak serupa itu telah dipandang sebagai obyek perhatian dan aksi internasional yang sah (Nickel, 1996 : 10).Secara definitif hak merupakan unsur normatif yang berfungsi sebagai pedoman berprilaku, melindungi kebebasan, kekebalan serta menjamin adanya peluang bagi manusia dalam menjaga harkat dan martabatnya. Hak mempunyai unsur-unsur sebagai berikut: pemilik hak, ruang lingkup penerapan hak dan pihak yang bersedia dalam penerapan hak (Nickel, 1996 : 199).Ketiga unsur tersebut menyatu dalam pengertian dasar hak. Dengan demikian hak merupakan unsur normatif yang melekat pada diri setiap manusia yang dalam penerapannya berada pada ruang lingkup hak persamaan dan hak kebebasan yang terkait dengan interaksinya antara individu atau dengan instansi. HAM juga berarti hak-hak yang melekat pada manusia berdasarkan kodratnya, jadi hak yang dimiliki manusia sebagai manusia (Setiarja, 1993: 73).

Tahun 1986 persoalan lingkungan sudah diadopsi oleh Majelis Umum PBB sebagai salah satu dari hak asasi generasi ketiga yang di dalamnya mencakup hakhak kolektif suatu kelompok masyarakat untuk menentukan nasib sendiri dan hak untuk membangun, menurut Dev et al. mencakup:

. . . environmental, cultural and developmental rights. They are concerned with rights of groups and peoples rather than of individuals and include such rights as the right of self-determination and the right to development. The developing countries have played a leading role in bringing about international concensus on these rights (Arjun at all, 1996).

Kebijakan pembangunan di wilayah pesisir saat ini berpengaruh terhadap kondisi lingkungan, aktifitas ekonomi di 
wilayah pesisir oleh pemodal menyebabkan menurunnya kualitas lingkungan hidup. Masyarakat di wilayah pesisir pada kenyataannya telah kehilangan hak atas lingkungan wilayahnya. Akibatnya masih banyak penduduk di wilayah pesisir hidup dalam garis kemiskinan dan hidup pada lingkungan yang buruk. Kenyataan ini sangatlah kontradiktif dengan semangat konstitusi yang banyak memberikan jaminan terhadap perlindungan HAM. Pasal 1 Piagam Hak Asasi Manusia dimuat ketentuan tentang hak untuk hidup yang berbunyi, "Setiap orang berhak untuk hidup, mempertahankan hidup dan kehidupannya," namun dalam Pasal 36 juga dimuat pembatasan terhadap hak asasi manusia termasuk hak untuk hidup sebagai berikut:

"Di dalam menjalankan hak dan kebebasannya setiap orang wajib tunduk kepada pembatasanpembatasan yang ditetapkan oleh Undang-undang dengan maksud semata mata untuk menjamin pengakuan serta penghormatan atas hak dan kebebasan orang lain, dan untuk memenuhi tuntutan yang adil sesuai dengan pertimbangan moral, keamanan, dan ketertiban umum dalam suatu masyarakat demokratis".

Konsideran huruf a UU No. 32 Tahun 2009 tentang Perlindungan dan Pengelolaan Lingkungan Hidup (UUPPLH) disebutkan bahwa: "Lingkungan hidup yang baik dan sehat merupakan hak asasi setiap warga negara Indonesia sebagaimana diamanatkan dalam Pasal $28 H$ UndangUndang Dasar Negara Republik Indonesia Tahun 1945" (Konsideran UUPPLH). Pada Pasal 3 UUPPLH disebutkan bahwa perlindungan dan pengelolaan lingkungan hidup bertujuan: a. melindungi wilayah Negara Kesatuan Republik Indonesia dari pencemaran dan/atau kerusakan lingkungan hidup; b. menjamin keselamatan, kesehatan, dan kehidupan manusia; c. menjamin kelangsungan kehidupan makhluk hidup dan kelestarian ekosistem; d. menjaga kelestarian fungsi lingkungan hidup; e. mencapai keserasian, keselarasan, dan keseimbangan lingkungan hidup; $\mathrm{f}$. menjamin terpenuhinya keadilan generasi masa kini dan generasi masa depan; g. menjamin pemenuhan dan perlindungan hak atas lingkungan hidup sebagai bagian 
dari hak asasi manusia; h. mengendalikan pemanfaatan sumber daya alam secara bijaksana; i. mewujudkanpembangunan berkelanjutan; dan j. mengantisipasi isu lingkungan global (Pasal 3 UUPPLH).

Ketentuan mengenai lingkungan hidup dirumuskan dalam Pasal 28H ayat (1) dan Pasal 33 ayat (4) UUD 1945. Pasal 28H ayat (1) UUD 1945 menentukan, "Setiap orang berhak hidup sejahtera lahir dan batin, bertempat tinggal, dan mendapatkan lingkungan hidup yang baik dan sehat serta berhak memperoleh pelayanan kesehatan." Hak untuk memperoleh lingkungan hidup yang baik dan sehat serta pelayanan kesehatan yang baik, merupakan hak asasi manusia. Karena itu, UUD 1945 jelas sangat pro lingkungan hidup, sehingga dapat disebut sebagai konstitusi hijau (green constitution).

Ada dua konsep yang berkaitan dengan ide tentang ekosistem, yaitu bahwa perekonomian nasional berdasar atas demokrasi ekonomi dimaksud haruslah mengandung prinsip: (i) berkelanjutan, dan (ii) berwawasan lingkungan (Jimly Asshidiqie, 2010: 94).Dengan sendirinya keseluruhan ekosistem seperti yang dimaksud dalam
Pasal 33 ayat (3) sebagaimana ditafsirkan secara ekstensif dan kreatif oleh pelbagai undang-undang di bidang lingkungan hidup, haruslah dikelola untuk kepentingan pembangunan berdasarkan prinsip-prinsip berkelanjutan (sustainable development) dan wawasan lingkungan (pro-environment) sebagaimana ditentukan oleh Pasal 33 ayat (4) UUD 1945. Oleh karena itu, cukup alasan untuk menyebut bahwa UUD 1945 pasca reformasi atau sesudah Perubahan Keempat pada 2002 ini juga sudah berwarna hijau atau green constitution ( Jimly Asshidiqie, 2010 : 94).

Lingkungan yang indah dan lestari akan membawa pengaruh positif bagi kesehatan dan bahkan keselamatan manusia, sebaliknya, lingkungan yang buruk bagi kehidupan manusia. Tindakan eksploitatif manipulatif terhadap alam akan mengakibatkan kerusakan langsung terhadap alam, dan secara tidak langsung hal itu akan berdampak negatif bagi kehidupan manusia khususnya, dan kehidupan berbagai mahluk lain pada umumnya. Sebaliknya, apabila manusia menunjukkan kasih sayang yang besar terhadap alam, dengan memelihara dan melestarikannya, maka alam akan 
menjamin kelangsungan hidup manusia dalam suasana nyaman dan menyenangkan.

\section{Abetnego Tarigan, Direktur}

Eksekutif Nasional WALHI menegaskan bahwa "dalam konteks hak asasi manusia, WALHI ingin kembali menegaskan kewajiban negara untuk memberikan jaminan perlindungan, penghormatan dan pemenuhan terhadap hak atas lingkungan hidup. Artinya, negara justru harusnya berada di garda terdepan untuk mendesak tanggungjawab korporasi atas kejahatan lingkungan dan kemanusiaan yang telah dilakukan. Ini mensyaratkan negara tidak boleh tunduk dengan kekuatan korporasi" http://www.walhi.or.id/hak-ataslingkungan-hidup-adalah-hak-asasimanusia-memutus-lingkar-korupsi-dankejahatan-lingkungan.html, diunduh pada 8 Juli2016) .Sejak tahun 2003, WALHI telah melakukan kampanye bahwa hak atas lingkungan hidup yang baik dan sehat sebagai hak asasi manusia. Suara ini juga perlu terus dikampanyekan mengingat sumber daya alam justru digeser menjadi sebuah komoditas melalui komodifikasi dan finansialisasi sumber daya alam. Isu lingkungan hidup juga dibajak dengan berbagai kemasan "hijau" yang justru akan semakin melanggengkan konflik sumber daya alam dan melanggar hak asasi manusia (Jimly Asshidiqie, 2010 : 94).

Sebagai imbangan adanya hak asasi setiap orang itu, berarti negara diharuskan untuk menjamin terpenuhinya hak setiap orang untuk memperoleh lingkungan hidup yang baik dan sehat yang termasuk kategori hak asasi manusia tersebut. Sebagai hak setiap orang, tentunya secara bertimbal-balik pula mewajibkan semua orang untuk menghormati hak orang lain sehubungan dengan lingkungan yang baik dan sehat itu. Oleh karena itu, di satu segi setiap orang berhak atas lingkungan hidup yang baik dan sehat, tetapi di pihak lain setiap orang juga berkewajiban untuk menjaga dan menghormati hak orang lain untuk mendapatkan dan menikmati lingkungan hidup yang baik dan sehat itu. Demikian pula negara, di samping dibebani kewajiban dan tanggung jawab untuk menjamin lingkungan hidup yang baik dan sehat, juga berhak menuntut setiap orang untuk menghormati hak orang lain, dan apabila perlu memaksa setiap orang untuk tidak merusak dan mencemarkan lingkungan hidup untuk kepentingan bersama. 


\section{Simpulan}

Wilayah pesisir merupakan sumber daya milik bersama (common property) dengan mengakui hak masyarakat pesisir untuk dapat mengelola dan memanfaatkannya, maka hal ini mencerminkan makna yang termaktub dalam Pasal 33 ayat (3) UUD 1945, bahwa sebagai bagian dari rakyat Indonesia masyarakat di wilayah pesisir berhak untuk menikmati sebesar besar kemakmuran atas sumber daya pesisir. Tindakan eksploitasi dan kegiatan yang berdampak terhadap rusaknya wilayah pesisir oleh pihak-pihak tertentu yang menghilangkan sumber kehidupan dan penghidupan masyarakat pesisir adalah sebuah pelanggaran kepemilikan kolektif rakyat atas sumber daya pesisir.

Perbuatan pencemaran dan perusakan lingkungan hidup di wilayah pesisir merupakan pelanggaran terhadap hak asasi manusia, karena setiap manusia berhak atas lingkungan hidup yang baik dan sehat, sebagaimana telah dilindungi oleh Pasal 28H ayat (1) UUD 1945 dan UU No. 32 Tahun 2009 tentang Perlindungan dan Pengelolaan Lingkungan Hidup

\section{Saran}

Jangka panjang kesalahan dan kegagalan yang bersumber dari instrumen hukum dalam pengelolaan sumber daya pesisir yang tidak memberikan perlindungan terhadap masyarakat hendaknya dirubah melalui pembentukan peraturan perundang-undangan yang tidak berorientasi semata mata mengejar pertumbuhan pembanguan ekonomi dengan mengabaikan kemakmuran rakyat dan kelestrian lingkungan selain itu perlunya proses pendidikan hukum yang benar dan bermakna akan arti penting hubungan manusia dan alam.

\section{Daftar Rujukan}

A. Gunawan Setiardja (1993), Hak-Hak Asasi Manusia Berdasarkan Ideologi Pancasila, Yogyakarta, Kanisius.

Bagong Suyanto, "Sosiologi Masyarakat Pesisir", Makalah disampaikan pada Diklat Himpunan Ahli Pesisir Indonesia (HAPPI), April 2016, di Hotel Ibis Basra Surabaya.

Dev, Arjun, et al.(1996), Human Rights: A Source Book, National Council of Educational Research and Training, New Delhi.

James W. Nickel (1996), Making Sense of Human Rights Philosophical Reflection on the Universal Declaration of Human Rights, Alih bahasa: Titi S. Dan Eddy Arini, Jakarta, Gramedia. 
Jimly Asshidiqie (2010), Green Conctitution "Nuansa Hijau Undnag-Undang Dasar Negara Republik Indonesia Tahun 1945”, Jakarta, Rajawali Pers.

Rokhmin Dahuri dan Iwan Nugroho (2012), Pembangunan Wilayah : Perspektif Ekonomi, Sosial dan Lingkungan, (Ed. Rev, cet.2, Jakarta, LP3ES.

Tim ICCE UIN Jakarta (2003), Demokrasi, Hak Asasi Manusia, Masyarakat Madani.

T. Mulya Lubis (1987), Hak Asasi Manusia dan Pembangunan, Jakarta: Yayasan LBHI.

http://www.dephut.go.id/uploads/INFOR MASI/RRL/STS_MAngrove.HTM "Perubahan Kondisi Kawasan Pantai", di unduh pada 7 Juli 2016.

http://www.walhi.or.id/hak-ataslingkungan-hidup-adalah-hak-asasimanusia-memutus-lingkar-korupsi-dankejahatan-lingkungan.html, diunduh pada 8 Juli2016

Undang-undang Dasar Republik Indonesia 1945

Undang-undang Nomor 5 Tahun 1960, Lembara Negara Republik Indonesia (LNRI) Tahun 1960 Nomor 104 Tambahan Lembaran Negara(TLN) Tahun 1960 Nomor 2043 tentang Peraturan Dasar Pokok-Pokok Agraria

Undang-undang Nomor 27 Tahun 2007 tentang Pengelolaan Wilayah
Pesisir Dan Pulau-Pulau Kecil Lembaran Negara Republik Indonesia Nomor 84, Tambahan Lembaran Negara Republik Indonesia Nomor 4739 disahkan di Jakarta tanggal 17 Juli 2007

Undang-undang Nomor 26 Tahun 2007 tentang Penataan Ruang Nasional, Lembaran Negara Republik Indonesia tahun 2007 Nomor 68, Tambahan Lembaran Negara Republik Indonesia Nomor 4725 yang disahkan pada tanggal 26 April 2007

Uundang-undang Nomor 1 Tahun 2014 tentang Perubahan Atas Undangundang Nomor 27 Tahun 2007 tentang Pengelolaan Wilayah Pesisir dan Pulau-Pulau Kecil, (Lembaran Negara Tahun 2014 Nomor 2, Tambahan Lembaran Negara Republik Indonesia Nomor 5490).

Undang-undang Nomor 32 Tahun 2009 tentang Perlindungan dan Pengelolaan Lingkungan Hidup (Lembaran Negara Republik Indonesia Tahun 2009 Nomor 140, Tambahan Lembaran Negara Republik Indonesia Nomor 5059). 